\title{
A decade of EGFR inhibition in EGFR-mutated non small cell lung cancer (NSCLC): Old successes and future perspectives
}

\author{
Alessandro Russo ${ }^{1}$, Tindara Franchina ${ }^{1}$, Giuseppina Rosaria Rita Ricciardi ${ }^{1}$, \\ Antonio Picone ${ }^{1}$, Giuseppa Ferraro ${ }^{1}$, Mariangela Zanghì ${ }^{1}$, Giuseppe Toscano ${ }^{1}$, \\ Antonio Giordano ${ }^{2}$, Vincenzo Adamo ${ }^{1}$ \\ ${ }^{1}$ Medical Oncology Unit AOOR Papardo-Piemonte \& Department of Human Pathology, University of Messina, Messina, Italy \\ ${ }^{2}$ Sbarro Institute for Cancer Research and Molecular Medicine, Center for Biotechnology, Temple University, Philadelphia, \\ Pennsylvania, USA
}

Correspondence to:

Vincenzo Adamo, e-mail: vadamo@unime.it

Keywords: EGFR mutations, third generation EGFR TKIs, non small cell lung cancer, tyrosine kinase inhibitors, targeted therapy

Received: April 25, $2015 \quad$ Accepted: June 01, $2015 \quad$ Published: June 12, 2015

\section{ABSTRACT}

The discovery of Epidermal Growth Factor Receptor (EGFR) mutations in Non Small Cell Lung Cancer (NSCLC) launched the era of personalized medicine in advanced NSCLC, leading to a dramatic shift in the therapeutic landscape of this disease. After ten years from the individuation of activating mutations in the tyrosine kinase domain of the EGFR in NSCLC patients responding to the EGFR tyrosine kinase inhibitor (TKI) Gefitinib, several progresses have been done and first line treatment with EGFR TKIs is a firmly established option in advanced EGFR-mutated NSCLC patients. During the last decade, different EGFR TKIs have been developed and three inhibitors have been approved so far in these selected patients. However, despite great breakthroughs have been made, treatment of these molecularly selected patients poses novel therapeutic challenges, such as emerging of acquired resistance, brain metastases development or the need to translate these treatments in earlier clinical settings, such as adjuvant therapy.

The aim of this paper is to provide a comprehensive review of the major progresses reported so far in the EGFR inhibition in this molecularly-selected subgroup of NSCLC patients, from the early successes with first generation EGFR TKIs, Erlotinib and Gefitinib, to the novel irreversible and mutant-selective inhibitors and ultimately the emerging challenges that we, in the next future, are called to deal with.

\section{INTRODUCTION}

The discovery of Epidermal Growth Factor Receptor (EGFR) mutations in NSCLC launched the era of personalized medicine in advanced Non Small Cell Lung Cancer (NSCLC), leading to a dramatic shift in the therapeutic landscape of this disease from a "one size fits all" approach to the treatment selection on molecular characteristics of tumors $[1,2]$. After ten years from the individuation of activating mutations in the tyrosine kinase domain of the EGFR in NSCLC patients responding to the EGFR tyrosine kinase inhibitor (TKI) Gefitinib, several progresses have been done and first line treatment with EGFR TKIs is a firmly established option in advanced EGFR-mutated NSCLC patients. During the last decade, different EGFR TKIs have been developed and three inhibitors (Gefitinib, Erlotinib and, more recently, Afatinib) have been approved so far in these selected patients (Figure 1).

However, despite great breakthroughs have been made, treatment of these molecularly selected patients poses novel therapeutic challenges, such as emerging of acquired resistance, brain metastases development or the need to translate these treatments in earlier clinical settings, such as adjuvant therapy.

The aim of this paper is to provide a comprehensive review of the major progresses reported so far in the EGFR inhibition in this molecularly-selected subgroup of NSCLC patients, from the early successes with first generation EGFR TKIs, Erlotinib and Gefitinib, to the 


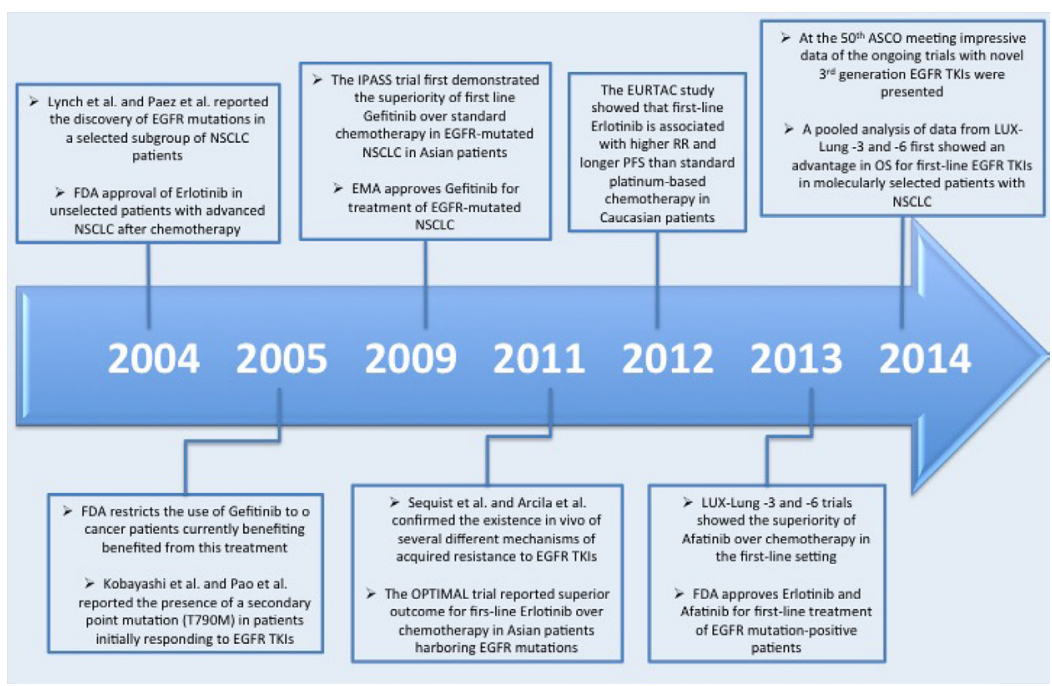

Figure 1: Timeline of the major progresses in the last decade in EGFR-mutated NSCLCs.

novel irreversible and mutant-selective inhibitors and ultimately the emerging challenges that we, in the next future, are called to deal with.

\section{The discovery of EGFR mutations}

The Epidermal Growth Factor Receptor (EGFR) is a tyrosine kinase (TK) receptor that is activated upon binding to the Epidermal Growth Factor and other growth factor ligands, triggering several downstream pathways, including RAS/MAPK, PI3K/Akt and STAT that regulate different cellular processes, including DNA synthesis and proliferation. EGFR signaling is commonly deregulated in cancer through different mechanisms, including genetic mutations of the receptor [2,3]. Mutant forms of EGFR have different trafficking compared with the wild type receptor, since some of the regulatory proteins that balance the EGFR pathway present altered expression in cancer [4].

In 2004 two different groups simultaneously identified the presence of somatic mutations in the tyrosine kinase domain of the EGFR in a small group of patients with NSCLC responding to the EGFR tyrosine kinase inhibitor (TKI) Gefitinib [5, 6]. These somatic mutations were associated with in vitro sensitivity to Gefitinib and with clinic-pathological characteristics preliminary associated with clinical activity [7, 8]: Asian ethnicity, female sex, adenocarcinoma histology and never smoking status. In addition, EGFR mutations were also associated with TTF-1 expression [9]. These somatic mutations mainly target the exons 18-21 of the gene, which encodes part of the TK domain of the EGFR (encoded by exons 18-24) and are clustered around the ATP-binding pocket of the receptor. The most common and best characterized EGFR mutations are in-frame deletions in exon 19, which eliminates the conserved motif LREA (residues 747-750), and the exon 21 L858R substitutions, that together constitute $\sim 80-90 \%$ of all EGFR mutations in NSCLC. These mutations are commonly referred as "activating mutations" as they are constitutive activated and oncogenic. These mutant kinases present a reduced affinity for the ATP, accounting for the increased sensitivity to EGFR TKIs compared with the wild type counterparts, since these inhibitors compete with ATP for binding to the catalytic site [10-12].

With the exception of PI3KCA mutations [13], the majority of oncogenic drivers in NSCLC are usually mutually exclusive, including EGFR mutations.

Some authors have suggested a differential sensitivity to EGFR TKIs for exon 19 deletions and exon 21 L858R point mutations, with the former associated with longer overall survival (OS) and progression-free survival (PFS) $[14,15]$. These preliminary observations were confirmed in clinical trials [16-18], although others have did not find any correlation $[19,20]$. Recent meta-analyses addressed this question and reported that patients harboring exon 19 deletions are associated with a reduced progression risk than those with exon 21 point mutations [21-23] and a longer OS [22, 23]. However, the exact mechanism of this association remains largely elusive and might involve differential sensitivity to EGFR TKIs, different mechanism of acquired resistance as well as different frequency of compound mutations [21]. These data have important clinical consequences since stratification for the type of EGFR mutation might represent an important factor to consider in clinical trials with EGFR TKIs.

Oncogene addicted tumors, such as EGFR mutated NSCLCs, may present peculiar patterns of metastatization compared with wild type tumors, including a more frequent liver involvement at the diagnosis [24], higher tendency to central nervous system metastatization [25-27] and higher likelihood of brain metastases detection at first presentation [28] diffuse and/or miliary 
pulmonary metastases [28, 29]. However, others did not find any differences in brain and bone metastases development between EGFR-mutated patients and wild type [30] or significant differences in number, neuroanatomic location or size of brain metastases [31].

Moreover, some authors have suggested a possible interaction between EGFR mutation type and site of metastatization. For instance, Sekine et al. reported that patients harboring exon 19 deletions present a peculiar pattern of brain metastatization that resemble to that of miliary brain metastases, with multiple and small brain tumors with minimal peritumoral edema [32].

In addition to classic "common mutations" $\sim 10 \%$ of patients with EGFR mutations may ehibit mutations in codons other than 19 and 21. Rare mutations could be detected in a small fraction of patients including exon 18 mutations, predominantly at G719 ( 3-4\%), exon 20 mutations $(\sim 4-5 \%)$ as well as uncommon mutations in exon 19 (for example, in-frame insertions) and 21 (i.e. L851Q/R), and finally compound mutations. The clinical significance of these rare mutants is not always fully understood with some variants associated with response to EGFR TKIs (for instance, exon 18 G719X) other associated with resistance (i.e. exon 20 T790M) and other with uncertain clinical significance [33-35]. The mechanism by which these mutations confer resistance to EGFR TKIs is not always fully understood, but a better knowledge of the molecular basis of their activity may help to overcome resistance in patients harboring these mutations [36].

The presence of EGFR mutations defines a specific molecular subgroup of NSCLC $(\sim 15 \%$ of Caucasian patients with adenocarcinomas) $[37,38]$ that respond to an EGFR TKI in over $60 \%$ of patients (Table 1). The role of these inhibitors in EGFR wild type tumors is instead more debatable, since the benefit in such patient is modest $(\sim 8 \%$ with Erlotinib in pretreated NSCLC) and no predictive biomarkers have been so far reported in this specific subset of patients [39].

Several phase III trials demonstrated the superiority of EGFR TKIs over chemotherapy in EGFR-mutated NSCLC in the first line setting in terms of overall response rate (ORR) and progression free survival (PFS), but not in overall survival (OS) due

\section{Table 1: Phase III trials showing superiority of EGFR TKIs over first-line chemotherapy in}

EGFR-mutated NSCLC patients

\begin{tabular}{|c|c|c|c|c|c|c|c|}
\hline Trial & $\begin{array}{l}\text { Selection } \\
\text { criteria }\end{array}$ & $\begin{array}{c}\text { Treatment } \\
\text { Arms }\end{array}$ & $N$ & RR (\%) & PFS (mo) & OS (mo) & References \\
\hline IPASS & $\begin{array}{l}\text { East-Asian, light/ } \\
\text { non-smoker, } \\
\text { adenocarcinoma }\end{array}$ & $\begin{array}{l}\text { Gefitinib vs. } \\
\text { Carboplatin/ } \\
\text { Paclitaxel }\end{array}$ & 132 vs. 129 & 71.2 vs. 47.3 & 9.6 vs. 6.3 & 21.6 vs. 21.9 & {$[17,63]$} \\
\hline $\begin{array}{l}\text { First- } \\
\text { SIGNAL }\end{array}$ & $\begin{array}{l}\text { Korean, } \\
\text { non-smoker, } \\
\text { adenocarcinoma }\end{array}$ & $\begin{array}{l}\text { Gefitinib vs. } \\
\text { Cisplatin/ } \\
\text { Gemcitabine }\end{array}$ & 26 vs. 16 & 84.6 vs. 37.5 & 8.0 vs. 6.3 & 27.2 vs. 25.6 & [64] \\
\hline $\begin{array}{l}\text { WJTOG } \\
3405\end{array}$ & $\begin{array}{l}\text { Japanese, EGFR } \\
\text { mutation }\end{array}$ & $\begin{array}{l}\text { Gefitinib vs. } \\
\text { Cisplatin/ } \\
\text { Docetaxel }\end{array}$ & 86 vs. 86 & 62.1 vs. 32.1 & 9.2 vs. 6.3 & 35.5 vs. 38.8 & {$[16,107]$} \\
\hline NEJ 002 & $\begin{array}{l}\text { Japanese, EGFR } \\
\text { mutation }\end{array}$ & $\begin{array}{l}\text { Gefitinib vs. } \\
\text { Carboplatin/ } \\
\text { Paclitaxel }\end{array}$ & 114 vs. 114 & 73.7 vs. 30.7 & 10.8 vs. 5.4 & 27.7 vs. 26.6 & {$[44,108]$} \\
\hline OPTIMAL & $\begin{array}{l}\text { Chinese, EGFR } \\
\text { mutation }\end{array}$ & $\begin{array}{l}\text { Erlotinib vs. } \\
\text { Carboplatin/ } \\
\text { Gemcitabine }\end{array}$ & 82 vs. 72 & 83 vs. 36 & 13.1 vs. 4.6 & 22.7 vs. 28.9 & {$[65,109]$} \\
\hline EURTAC & $\begin{array}{l}\text { European, EGFR } \\
\text { mutation }\end{array}$ & $\begin{array}{l}\text { Erlotinib vs. } \\
\text { Platinum agent } \\
\text { + Gemcitabine } \\
\text { or Docetaxel }\end{array}$ & 86 vs. 87 & 58 vs. 15 & 9.7 vs. 5.2 & 19.3 vs. 19.5 & {$[66]$} \\
\hline LUX-Lung 3 & $\begin{array}{l}\text { Asian and } \\
\text { European, EGFR } \\
\text { mutation }\end{array}$ & $\begin{array}{l}\text { Afatinib vs. } \\
\text { Cisplatin/ } \\
\text { Pemetrexed }\end{array}$ & 230 vs. 115 & 56.1 vs. 22.6 & 11.1 vs. 6.9 & \multirow{2}{*}{25.8 vs. 24.5} & {$[18,79]$} \\
\hline LUX-Lung 6 & $\begin{array}{l}\text { Asian, EGFR } \\
\text { mutation }\end{array}$ & $\begin{array}{l}\text { Afatinib vs. } \\
\text { Cisplatin/ } \\
\text { Gemcitabine }\end{array}$ & 242 vs. 122 & 66.9 vs. 23.0 & 11.0 vs. 5.6 & & {$[18,80]$} \\
\hline
\end{tabular}


to the extensive cross-over between treatment arms, although recently a pooled analysis of patients harboring common mutations enrolled in the LUX-Lung-3 and -6 trials reported a survival advantage also [18]. Since no survival gain was demonstrated in the phase III trials conducted so far, the use of EGFR TKIs in EGFRmutated patients in first- or second-line should not influence the eventual survival outcome, as demonstrated in the phase II trial of the Spanish Lung Cancer Group [40]. However, retrospective analyses of large phase III trials reported inferior ORR than commonly observed in the front-line setting in EGFR-mutated patients treated with EGFR TKIs after chemotherapy [41-44]. A possible explanation might come from studies that reported an influence of chemotherapy on EGFR mutation status, with lower mutational rate in patients previously treated with chemotherapy $[45,46]$. Chemotherapy may selectively kill and inhibit mutant clones within the tumor, whereas wild type clones may proliferate, altering the relative proportion of EGFR-mutated/EGFR-wild type cells within the tumor mass. A direct observation of increased sensitivity to chemotherapy is the fact that patients with EGFR mutations usually exhibit increased ORR to first-line chemotherapy [47]. These studies underlie another emerging problem, the presence of tumor heterogeneity.

In 2012 in a seminal paper Gerlinger and coll. reported evidence of intratumor heterogeneity and spatial separation of subclones in metastatic renal cancer, establishing the "branched evolution" hypothesis [48], suggesting that biomarker sampling in a single tumor region may undetect the complex genomic landscape of a tumor, providing major challenges to clinical implementation of personalized medicine and biomarker development. Two recent papers addressed this issue in NSCLC also. De Bruin et al. reported spatial and temporal tumor heterogeneity of driver mutations within NSCLC, raising the possibility that a single-region sampling biopsy, as commonly done in clinical practice, could miss clinical-relevant driver events present in specific tumor subclones [49]. In contrast, Zhang et al. did not found substantial differences within the same tumor in driver mutations, suggesting that single-biopsy analysis might be sufficient to identify the majority of known driver mutations in lung adenocarcinomas [50]. In addition, a high concordance rate for recurrent somatic alterations has been reported between primary NSCLC and metastases, suggesting that a new biopsy for genomic information to guide treatment decision may not necessary when it is present an archived primary material, since key driver oncogenic events seems to occur early in NSCLC tumorigenesis [51].

Further studies are required to throw a light on this controversial issue and therefore use of a singlesite biopsy should continue to be the standard in clinical practice.

\section{EGFR inhibition in EGFR-addicted NSCLC: A successful 10-year story}

The clinical development of EGFR inhibitors in NSCLC started before the discovery of EGFR mutations, therefore initial studies with Gefitinib and Erlotinib were conducted in unselected patients in both pretreated [52-54] and in treatment-naïve patients in combination with standard chemotherapy [55-58]. In attempt to identify patients with improved outcome when treated with EGFR TKIs, several predictive biomarkers, such as EGFR overexpression/amplification [59] and HER2 overexpression/amplification [60], were studied before EGFR mutations emerged as the major predictive factor to these targeted agents. The discovery of EGFR mutations and the dramatic responses observed with EGFR TKIs in retrospective and small phase II studies [20, 61, 62] paved the way to a paradigm shift in the clinical trial design, favoring the development of clinically and then molecularly selected studies in NSCLC. Gefitinib was the first EGFR TKI receiving regulatory approval for EGFR-mutated NSCLC patients after the publication of the results of the IPASS (Iressa Pan-Asia Study) trial, reporting a significant advantage in terms of PFS and ORR for first-line Gefitinib versus Carboplatin/Paclitaxel [63]. Several other trials conducted in Asia confirmed the superiority of Gefitinib over chemotherapy in EGFRmutated patients [16, 44, 64].

The extension of approval of Erlotinib for patients harboring EGFR mutations, in addition to the previous indication for unselected patients with NSCLC after at least one chemotherapeutic line, was obtained after the publication of two large phase III trials conducted in Asia [65] and Europe [66], providing the definitive demonstration of superiority of an EGFR TKI over standard first-line chemotherapy in molecularly selected patients.

Unfortunately, despite initial responses, virtually all patients, ultimately, progress because of the acquisition of resistance. In addition, a proportion of patients with EGFR mutations exhibits de novo resistance and does not respond to TKIs treatment. Several mechanisms of primary and acquired resistance to EGFR TKIs $[67,68]$ have been so far reported in in vitro NSCLC models and some have also been confirmed in patients. Some of these mechanisms seem to be mutually exclusive, although distinct mechanisms of resistance may be operative in the same tumors $[69,70]$. Several strategies have been developed for overcoming acquired resistance to the EGFR TKIs [71, 72] and the use of irreversible, covalent-binding, EGFR TKIs (the so called "second generation" inhibitors) has been historically one of the most extensively studied. Despite promising preclinical evidences of activity against EGFR-mutated cell lines harboring the gatekeeper T790M mutation [7375] the most frequent mechanism of acquired resistance ( $\sim 50-60 \%$ after rebiopsy) $[69,70]$, neither Afatinib [76] nor Neratinib [77] nor Dacomitinib [78] demonstrated 
significant activity as single agent in patients harboring the T790M mutations. The failure of this strategy is probably due to the high drug concentrations required for reverting acquired resistance that are not achievable in clinical practice because of inacceptable toxicity, due to the activity of these agents against wild type EGFR. Instead, their role is more defined in the front-line treatment of NSCLC patients harboring EGFR activating mutations. Recently, Afatinib received regulatory approval in the first line setting after the publication of the LUX-Lung-3 and -6 trials $[79,80]$ and another irreversible EGFR inhibitor, Dacomitinib, has reported promising results in a phase II study [81]. Ongoing comparative phase III trials (ARCHER 1050, LUX-Lung-7) will provide definitive evidences whether these agents are superior than first-generation EGFR TKIs (i.e. Gefitinib and Erlotinib) in this clinical setting.

However, the role of second generation EGFR TKIs in acquired resistance is not definitely thrown over, since combining these agents with other targeted agents, such as the dual combination Afatinib plus Cetuxumab [82] and Neratinib plus Temsirolimus [83], has recently reported promising results, albeit toxicity profile of these combinations could limit their clinical implementation. The SWOG 1403 study is ongoing and will evaluate Cetuximab-Afatinib combination in the first-line setting in patients harboring EGFR sensitizing mutations.

In attempt to overcome the limits of secondgeneration EGFR inhibitors, a novel class of mutantselective inhibitors has been developed. The first in class third generation inhibitor, named WZ4002, was discovered in 2009 [84], through a functional pharmacological screens against T790M mutant kinases. Unlike other EGFR TKIs that possess a structurally related quinazoline-based core scaffold and were identified as ATP-competitive inhibitors of wild type EGFR, WZ4002 is a covalent pyrimidine EGFR inhibitor specifically designed against EGFR T790M that is 30-100 fold more potent against EGFR T790M, and up to 100 fold less potent against wild type EGFR than quinazoline based EGFR inhibitors in vitro and is effective in murine models of lung cancer driven by EGFR T790M [84]. WZ4002 did not progress into human clinical trials, but three different mutant-selective irreversible inhibitors (Rociletinib, AZD9291 and HM61713) have recently reported in vivo impressive activity in patients with acquired resistance to EGFR TKIs. Rociletinib (also known as CO1686) is structurally related to WZ4002 and is the first drug of its class in clinical development for the treatment of T790M-positive NSCLC. In vitro and in vivo studies demonstrated that Rociletinib irreversibly and selectively inhibits mutant EGFR, including T790M mutation, with minimal activity against wild type EGFR, suggesting that drug tolerability to this agent may be superior to first and second generation EGFR inhibitors, for which major toxicities (diarrhea, skin rash and interstitial lung disease) are attributed to wild type EGFR blockage. Interestingly, NSCLC cells resistant to Rociletinib do not exhibit secondary mutations of the EGFR or amplification of the EGFR gene, but increased expression of genes involved in the epithelial-mesenchimal transtition (EMT) and Akt pathway [85]. Recently, Sequist and coll. reported the preliminary results of the ongoing phase I/II study TIGER $\mathrm{X}$ in patients with NSCLC harboring EGFR mutations and T790M-positive that previously received an EGFR TKI. The results, albeit preliminary, are quite impressive with a 59\% ORR and a median PFS not yet reached, but exceeding 12 months. The safety profile of this agent is also interesting with the most common toxicity represented by hyperglycemia [86]. The expansion phase II cohort of the study is ongoing and three trials (TIGER 1-3) will be launched in different clinical settings. Another third generation EGFR inhibitor is AZD9291. This monoanilinopyrimidine compound is structurally distinct from other third generation EGFR TKIs and in preclinical studies potently inhibited signaling pathways and cellular growth in both EGFR-mutant and T790M-mutant cell lines in vitro, with lower activity against wild type EGFR lines, with profound and sustained tumor regression in EGFR mutant tumor xenograft and transgenic models [87]. In vitro data suggests the potential to target both HER2 and HER4 kinase activity, a property that may be important as HER2 amplification may mediate acquired resistance to EGFR TKI in 5-12\% of cases [70, 88]. AZD9291 also appears to be effective against other rare drug-sensitive EGFR mutants with low activity against EGFR exon 20 insertions [83]. AZD9291 demonstrated promising activity in a phase I study in patients with EGFR-TKI resistant NSCLC with an ORR of $51 \%$ and an impressive ORR of $62 \%$ in patients T790M-positive, with no dose-limiting toxicities and a maximum tolerated dose not defined [89]. Three ongoing trials are evaluating the activity of AZD9291 in T790M-positive NSCLC (AURA 1-3 trials). Based on these impressive preliminary results the US Food and Drug Administration (FDA) granted the breakthrough designation to both Rociletinib and AZD9291 for patients EGFR T790M-positive NSCLC progressing during an FDA-approved EGFR-TKI.

Preliminary results of a dose-escalating phase I study evaluating a third mutant-selective inhibitor, HM61713, has been recently presented. This inhibitor was well tolerated and reported a promising activity in EGFR-mutated NSCLC patients previously treated with an EGFR-TKI with a more prominent activity in T790Mpositive tumors (ORR 29.2\%, DCR 75.0\%) than T790Mnegative (ORR 11.8\%, DCR 55.9\%) [90]. The expansion part of the study is planned.

\section{Emerging challenges}

\section{Brain metastases}

The emergence of brain metastases (BM) represent a major issue in clinical practice and is associated with 
a dismal prognosis. Traditionally, systemic treatments were considered mostly ineffective on BMs, with RR of $23-50 \%$ with platinum-based combinations [91]. The low molecular weight, the good toxicity profile and the unprecedented RR and PFS observed make appealing the use of EGFR TKIs in patients harboring EGFR mutations with BMs. Retrospective studies and small phase II trials reported intriguing activity for EGFR TKIs in EGFRmutated patients with BMs, with RR ranging from $60 \%$ to $100 \%$ and complete response (CR) rates that ranges $40 \%$ [91, 92]. Therefore front-line use of EGFR TKIs in patients with asymptomatic BMs harboring EGFR mutations could be the preferable option in this setting, delaying the use of whole brain radiotherapy [93].

However, the degree of Blood Brain Barrier (BBB) penetration of EGFR TKI may be influenced by factors patients, such as the extent of central nervous (CNS) disease and prior CNS-directed therapies, explaining why the CNS may still act as a partial sanctuary site, with approximately $20 \%$ of patients with EGFR-mutant tumors developing BMs while on EGFR TKI therapy [94]. Different strategies have been hypothesized to overcome this inadequate drug exposure, such as high pulsatile dose of EGFR TKI [95] or, in case of oligoprogressive disease, use of TKI beyond progression with the addition of local ablative therapies [96, 97].

The recent results, albeit preliminary, with third generation EGFR inhibitors with responses seen even in the CNS are encouraging [86] and deserve further investigations.

\section{Translating the results from advanced setting to adjuvant therapy}

The use of EGFR TKIs is the standard of care in advanced/metastatic NSCLC with activating EGFR mutations, however their role in early-stage lung cancer is far less defined. Two large randomized trials evaluated the role of EGFR TKIs in unselected resected stage IBIIIA NSCLC. The BR.19 study started in 2002 when adjuvant chemotherapy was not considered standard of care in resected NSCLC. Therefore, in 2003 the study was amended to allow adjuvant chemotherapy, so only $17 \%$ of patients received adjuvant chemotherapy and 5\% adjuvant radiotherapy. The BR.19 randomized patients to receive Gefitinib $250 \mathrm{mg} / \mathrm{d}$ versus Placebo for 2 years [98]. After the publication of the dismal results of the SWOG S0023 trial [99], that reported a detrimental effect for Gefitinib maintenance after definitive chemo-radiotherapy the BR.19 study was prematurely closed. The results of the study demonstrated not only no an advantage in both DFS and $O S$ in the overall population and in the small subgroup of EGFR-mutated patients (4\%), but also a possible detrimental effect.

The detrimental effect observed even in EGFRmutated patients may be attributable to the low mutation rate observed in the study, that could not have a sufficient powerful effect on the study results [98]. The results of the RADIANT trial were recently reported. In this study 973 patients with resected stage IB-IIIA NSCLC were randomized to either Erlotinib $150 \mathrm{mg} / \mathrm{d}$ or placebo for 2 years with or without adjuvant chemotherapy. The study failed to demonstrate a DFS advantage in the overall population (50.5 months vs. 48.2 months), but a trend toward a longer DFS was observed in the subgroup of patients with EGFR mutation (16.5\%), albeit not statistically significant (46.4 months vs. 28.5 months) (HR $0.61,95 \%$ CI $0.38-0.98, p=0.039)[100,101]$. Moreover, a retrospective study of the Memorial Sloan-Kettering Cancer Center reported a significant reduction of risk of recurrence or death ( $\mathrm{HR} 0.43, p=0.001)$ and a trend toward improved OS (HR $0.50, p=0.076$ ) for patients with resected NSCLC treated with Erlotinib or Gefitinib with or without adjuvant chemotherapy [102].

Ongoing studies in resected EGFR-mutated NSCLC (NCT01405079; NCT01410214; WJOG6410L; NCI-2014-01508) will definitely provide evidence of efficacy of this strategy, as observed in other solid malignancies, such as Imatinib in GIST and Trastuzumab in HER2-positive Breast Cancer.

\section{Uncommon and resistance EGFR mutations}

Exon 19 in-frame deletions and point-mutation L858R of the exon 21 account for more than $90 \%$ of all EGFR mutations and are associated with sensitivity to EGFR TKIs.

However, efficacy data for the remaining $\sim 10 \%$ of EGFR mutations are lacking and mostly from retrospective analyses [34, 103]. Data from the LUX-Lung project were recently presented, showing the activity of Afatinib in the largest prospective dataset in patients with rare mutations. The picture emerging from this analysis is complex with high heterogeneity among this peculiar molecular subgroup. Patients with de novo T790M mutations or exon 20 insertions presented in general inferior ORR and shorter PFS and OS compared with patients harboring other uncommon mutations, such as exon 18 G719X and exon 21 L861Q, that exhibited a range of sensitivity similar to that of common mutations. However, in some cases with exon 20 insertions or T790M mutations durable control of the tumor was observed [104]. Data from the French ERMETIC-IFCT network reported similar findings, with poorer outcome for patients harboring exon 20 insertions, with the exception of more proximal mutations, compared with complex mutations and exon 18 mutations [105].

A more extensive comprehension of the mechanisms underlying EGFR TKI-sensitivity of these mutations should help to provide more effective strategies for patients harboring these rare mutants. Recently, Yasuda et al. described the chemical structure of the exon 20 mutations D770_N771insNPG, showing that the three amino-acid insertion forms a "wedge" that lock the $\mathrm{C}$ helix of the EGFR in its inward, active position. Therefore, the clinical 
resistance of this mutant is not due to steric hindrance with inhibitor binding, but simply not sensitizing to EGFR TKIs inhibition [36]. These findings may help through the screening of compound libraries identification of mutantselective inhibitors as with T790M-mutants. Moreover, it was demonstrated that exon 20 mutations (EGFR D770 P772del_insKG and D770 > GY), which are intrinsically associated with resistance to EGFR TKIs, activate EGFR by increasing the attractive electrostatic dimerization energies. This might provide the rationale for the use of anti-EGFR monoclonal antibodies in patients with such mutations, since cetuximab, by preventing receptor dimerization, may be associated with therapeutic activity [106].

\section{CONCLUSIONS}

Since the discovery of EGFR mutations in 2004, the therapeutic landscape of advanced NSCLC has dramatically changed with unprecedented results in this usually disappointing disease. However, the clinical success of this strategy is limited by several challenges with which we are called to deal, such as emergence of acquired resistance or treatment of rare and compound mutations. To date three different EGFR TKIs have been approved and no prospective data are available to guide optimal treatment selection in clinical practice. Ongoing comparative randomized studies between reversible and irreversible EGFR TKIs and the recent development of novel mutant-selective inhibitors in patients with acquired resistance will definitely provide definitive conclusions about the optimal therapeutic strategy in this molecularly selected subgroup of patients. Probably, there is no magic bullet that can cure cancer by blocking a single signaling pathway, however combining these inhibitors each other or with other no overlapping drugs and a better comprehension of inherited mechanisms of resistance to these targeted agents might provide more durable therapeutic successes with the hope, in a not so far future, to cure lung cancer.

\section{CONFLICTS OF INTEREST}

None.

\section{REFERENCES}

1. Dienstmann R, Martinez P, Felip E. Personalizing therapy with targeted agents in non-small cell lung cancer. Oncotarget. 2011; 2:165-77.

2. Shtivelman E, Hensing $T$, Simon GR, Dennis PA, Otterson GA, Bueno R, Salgia R. Molecular pathways and therapeutic targets in lung cancer. Oncotarget. 2014; 5:1392-433.

3. Zhang Z, Stiegler AL, Boggon TJ, Kobayashi S, Halmos B. EGFR-mutated lung cancer: a paradigm of molecular oncology. Oncotarget. 2010; 1:497-514.
4. Hampton KK, Craven RJ. Pathways driving the endocytosis of mutant and wild-type EGFR in cancer. Oncoscience. 2014; 1:504-12.

5. Paez JG, Jänne PA, Lee JC, Tracy S, Greulich H, Gabriel S, Herman P, Kaye FJ, Lindeman N, Boggon TJ, Naoki K, Sasaki H, Fujii Y, et al. EGFR mutations in lung cancer: correlation with clinical response to gefitinib therapy. Science. 2004; 304:1497-500.

6. Lynch TJ, Bell DW, Sordella R, Gurubhagavatula S, Okimoto RA, Brannigan BW, Harris PL, Haserlat SM, Supko JG, Haluska FG, Louis DN, Christiani DC, Settleman J, et al. Activating mutations in the epidermal growth factor receptor underlying responsiveness of non-small-cell lung cancer to gefitinib. N Engl J Med. 2004; 350:2129-39.

7. Kris MG, Natale RB, Herbst RS, Lynch TJ Jr, Prager D, Belani CP, Schiller JH, Kelly K, Spiridonidis H, Sandler A, Albain KS, Cella D, Wolf MK, et al. Efficacy of gefitinib, an inhibitor of the epidermal growth factor receptor tyrosine kinase, in symptomatic patients with non-small cell lung cancer: a randomized trial. JAMA. 2003; 290:2149-58.

8. Miller VA, Kris MG, Shah N, Patel J, Azzoli C, Gomez J, Krug LM, Pao W, Rizvi N, Pizzo B, Tyson L, Venkatraman E, Ben-Porat L, et al. Bronchioloalveolar pathologic subtype and smoking history predict sensitivity to gefitinib in advanced non-small-cell lung cancer. J Clin Oncol. 2004; 22:1103-9.

9. Somaiah N, Fidler MJ, Garrett-Mayer E, Wahlquist A, Shirai K, Buckingham L, Hensing T, Bonomi P, Simon GR. Epidermal growth factor receptor (EGFR) mutations are exceptionally rare in thyroid transcription factor (TTF-1)negative adenocarcinomas of the lung. Oncoscience. 2014; 1:5221-8. eCollection 2014.

10. Greulich H, Chen TH, Feng W, Jänne PA, Alvarez JV, Zappaterra M, Bulmer SE, Frank DA, Hahn WC, Sellers WR, Meyerson M. Oncogenic transformation by inhibitor-sensitive and -resistant EGFR mutants. PLoS Med. 2005; 2:e313.

11. Politi K, Zakowski MF, Fan PD, Schonfeld EA, Pao W, Varmus HE. Lung adenocarcinomas induced in mice by mutant EGF receptors found in human lung cancers respond to a tyrosine kinase inhibitor or to down-regulation of the receptors. Genes Dev. 2006; 20:1496-510.

12. Yun $\mathrm{CH}$, Boggon $\mathrm{TJ}$, Li Y, Woo MS, Greulich H, Meyerson M, Eck MJ. Structures of lung cancer-derived EGFR mutants and inhibitor complexes: mechanism of activation and insights into differential inhibitor sensitivity. Cancer Cell. 2007; 11:217-27.

13. Scheffler M, Bos M, Gardizi M, König K, Michels S, Fassunke J, Heydt C, Künstlinger H, Ihle M, Ueckeroth F, Albus K, Serke M, Gerigk U, et al. PIK3CA mutations in non-small cell lung cancer (NSCLC): Genetic heterogeneity, prognostic impact and incidence of prior malignancies. Oncotarget. 2015; 6:1315-26.

14. Jackman DM, Yeap BY, Sequist LV, Lindeman N, Holmes AJ, Joshi VA, Bell DW, Huberman MS, Halmos B, Rabin MS, Haber DA, Lynch TJ, Meyerson M, et al. Exon 
19 deletion mutations of epidermal growth factor receptor are associated with prolonged survival in non-small cell lung cancer patients treated with gefitinib or erlotinib. Clin Cancer Res. 2006; 12:3908-14.

15. Riely GJ, Pao W, Pham D, Li AR, Rizvi N, Venkatraman ES, Zakowski MF, Kris MG, Ladanyi M, Miller VA. Clinical course of patients with non-small cell lung cancer and epidermal growth factor receptor exon 19 and exon 21 mutations treated with gefitinib or erlotinib. Clin Cancer Res. 2006; 12:839-44.

16. Mitsudomi T, Morita S, Yatabe Y, Negoro S, Okamoto I, Tsurutani J, Seto T, Satouchi M, Tada H, Hirashima T, Asami K, Katakami N, Takada M, et al. Gefitinib versus cisplatin plus docetaxel in patients with non-small-cell lung cancer harbouring mutations of the epidermal growth factor receptor (WJTOG3405): an open label, randomised phase 3 trial. Lancet Oncol. 2010; 11:121-8.

17. Fukuoka M, Wu YL, Thongprasert S, Sunpaweravong P, Leong SS, Sriuranpong V, Chao TY, Nakagawa K, Chu DT, Saijo N, Duffield EL, Rukazenkov Y, Speake G, et al. Biomarker analyses and final overall survival results from a phase III, randomized, open-label, first-line study of gefitinib versus carboplatin/paclitaxel in clinically selected patients with advanced non-small-cell lung cancer in Asia (IPASS). J Clin Oncol. 2011; 29:2866-74.

18. Yang JC, Wu YL, Schuler M, Sebastian M, Popat S, Yamamoto N, Zhou C, Hu CP, O'Byrne K, Feng J, Lu S, Huang Y, Geater SL, et al. Afatinib versus cisplatin-based chemotherapy for EGFR mutation-positive lung adenocarcinoma (LUX-Lung 3 and LUX-Lung 6): analysis of overall survival data from two randomised, phase 3 trials. Lancet Oncol. 2015. pii:S1470-2045. 71173-8.

19. Cappuzzo F, Ligorio C, Jänne PA, Toschi L, Rossi E, Trisolini R, Paioli D, Holmes AJ, Magrini E, Finocchiaro G, Bartolini S, Cancellieri A, et al. Prospective study of gefitinib in epidermal growth factor receptor fluorescence in situ hybridization-positive/phospho-Akt-positive or never smoker patients with advanced non-small-cell lung cancer: the ONCOBELL trial. J Clin Oncol. 2007; 25:2248-55.

20. Sequist LV, Martins RG, Spigel D, Grunberg SM, Spira A, Jänne PA, Joshi VA, McCollum D, Evans TL, Muzikansky A, Kuhlmann GL, Han M, et al. First-line gefitinib in patients with advanced non-small-cell lung cancer harboring somatic EGFR mutations. J Clin Oncol. 2008; 26:2442-9.

21. Zhang Y, Sheng J, Kang S, Fang W, Yan Y, Hu Z, Hong S, Wu X, Qin T, Liang W, Zhang L. Patients with exon 19 deletion were associated with longer progression-free survival compared to those with L858R mutation after firstline EGFR-TKIs for advanced non-small cell lung cancer: a meta-analysis. PLoS One. 2014; 9:e107161.

22. Wang H, Huang J, Yu X, Han S, Yan X, Sun S, Zhu X. Different efficacy of EGFR tyrosine kinase inhibitors and prognosis in patients with subtypes of EGFR-mutated advanced non-small cell lung cancer: a meta-analysis. J Cancer Res Clin Oncol. 2014; 140:1901-9.
23. Lee CK, Wu YL, Ding PN, Lord SJ, Inoue A, Zhou C, Mitsudomi T, Rosell R, Pavlakis N, Links M, Gebski V, Gralla RJ, Yang JC. Impact of Specific Epidermal Growth Factor Receptor (EGFR) Mutations and Clinical Characteristics on Outcomes After Treatment With EGFR Tyrosine Kinase Inhibitors Versus Chemotherapy in EGFR-Mutant Lung Cancer: A Meta-Analysis. J Clin Oncol. 2015; Apr 20. pii: JCO.2014.58.1736. [Epub ahead of print].

24. Doebele RC, Lu X, Sumey C, Maxson DA, Weickhardt AJ, Oton AB, Bunn PA Jr, Barón AE, Franklin WA, Aisner DL, Varella-Garcia M, Camidge DR. Oncogene status predicts patterns of metastatic spread in treatment-naive nonsmall cell lung cancer. Cancer. 2012; 118:4502-11.

25. Matsumoto S, Takahashi K, Iwakawa R, Matsuno $Y$, Nakanishi Y, Kohno T, Shimizu E, Yokota J. Frequent EGFR mutations in brain metastases of lung adenocarcinoma. Int J Cancer. 2006; 119:1491-4.

26. Eichler AF, Kahle KT, Wang DL, Joshi VA, Willers H, Engelman JA, Lynch TJ, Sequist LV. EGFR mutation status and survival after diagnosis of brain metastasis in nonsmall cell lung cancer. Neuro Oncol. 2010; 12:1193-9.

27. Welsh JW, Komaki R, Amini A, Munsell MF, Unger W, Allen PK, Chang JY, Wefel JS, McGovern SL, Garland LL, Chen SS, Holt J, Liao Z, et al. Phase II trial of erlotinib plus concurrent whole-brain radiation therapy for patients with brain metastases from non-small-cell lung cancer. J Clin Oncol. 2013; 31:895-902.

28. Shin DY, Na II, Kim CH, Park S, Baek H, Yang SH. EGFR mutation and brain metastasis in pulmonary adenocarcinomas. J Thorac Oncol. 2014; 9:195-9.

29. Togashi Y, Masago K, Kubo T, Sakamori Y, Kim YH, Hatachi Y, Fukuhara A, Mio T, Togashi K, Mishima M. Association of diffuse, random pulmonary metastases, including miliary metastases, with epidermal growth factor receptor mutations in lung adenocarcinoma. Cancer. 2011; 117:819-25.

30. Hendriks LE, Smit EF, Vosse BA, Mellema WW, Heideman DA, Bootsma GP, Westenend M, Pitz C, de Vries GJ, Houben R, Grünberg K, Bendek M, Speel EJ, et al. EGFR mutated non-small cell lung cancer patients: more prone to development of bone and brain metastases? Lung Cancer. 2014; 84:86-91.

31. Mak KS, Gainor JF, Niemierko A, Oh KS, Willers H, Choi NC, Loeffler JS, Sequist LV, Shaw AT, Shih HA. Significance of targeted therapy and genetic alterations in EGFR, ALK, or KRAS on survival in patients with nonsmall cell lung cancer treated with radiotherapy for brain metastases. Neuro Oncol. 2015; 17:296-302.

32. Sekine A, Kato T, Hagiwara E, Shinohara T, Komagata T, Iwasawa T, Satoh H, Tamura K, Kasamatsu T, Hayashihara K, Saito T, Takahashi H, Ogura T. Metastatic brain tumors from non-small cell lung cancer with EGFR mutations: distinguishing influence of exon 19 deletion on radiographic features. Lung Cancer. 2012; 77:64-9. 
33. Massarelli E, Johnson FM, Erickson HS, Wistuba II, Papadimitrakopoulou V. Uncommon epidermal growth factor receptor mutations in non-small cell lung cancer and their mechanisms of EGFR tyrosine kinase inhibitors sensitivity and resistance. Lung Cancer. 2013; 80:235-41.

34. Wu JY, Yu CJ, Chang YC, Yang CH, Shih JY, Yang PC. Effectiveness of tyrosine kinase inhibitors on "uncommon" epidermal growth factor receptor mutations of unknown clinical significance in non-small cell lung cancer. Clin Cancer Res. 2011; 17:3812-21.

35. Kobayashi S, Canepa HM, Bailey AS, Nakayama S, Yamaguchi N, Goldstein MA, Huberman MS, Costa DB. Compound EGFR mutations and response to EGFR tyrosine kinase inhibitors. J Thorac Oncol. 2013; 8:45-51.

36. Yasuda H, Park E, Yun CH, Sng NJ, Lucena-Araujo AR, Yeo WL, Huberman MS, Cohen DW, Nakayama S, Ishioka K, Yamaguchi N, Hanna M, Oxnard GR, et al. Structural, biochemical, and clinical characterization of epidermal growth factor receptor (EGFR) exon 20 insertion mutations in lung cancer. Sci Transl Med. 2013; 5. $216 \mathrm{ra} 177$.

37. Cancer Genome Atlas Research Network . Comprehensive molecular profiling of lung adenocarcinoma. Nature. 2014; 511:543-50.

38. Kris MG, Johnson BE, Berry LD, Kwiatkowski DJ, Iafrate AJ, Wistuba II, Varella-Garcia M, Franklin WA, Aronson SL, Su PF, Shyr Y, Camidge DR, Sequist LV, et al. Using multiplexed assays of oncogenic drivers in lung cancers to select targeted drugs. JAMA. 2014; 311:1998-2006.

39. Laurie SA, Goss GD. Role of epidermal growth factor receptor inhibitors in epidermal growth factor receptor wild-type non-small-cell lung cancer. J Clin Oncol. 2013; 31:1061-9.

40. Rosell R, Moran T, Queralt C, Porta R, Cardenal F, Camps C, Majem M, Lopez-Vivanco G, Isla D, Provencio M, Insa A, Massuti B, Gonzalez-Larriba JL, et al. Screening for epidermal growth factor receptor mutations in lung cancer. N Engl J Med. 2009; 361:958-67.

41. Zhu CQ, da Cunha Santos G, Ding K, Sakurada A, Cutz JC, Liu N, Zhang T, Marrano P, Whitehead M, Squire JA, Kamel-Reid S, Seymour L, et al. Role of KRAS and EGFR as biomarkers of response to erlotinib in National Cancer Institute of Canada Clinical Trials Group Study, BR.21. J Clin Oncol. 2008; 26:4268-75.

42. Douillard JY, Shepherd FA, Hirsh V, Mok T, Socinski MA, Gervais R, Liao ML, Bischoff H, Reck M, Sellers MV, Watkins CL, Speake G, et al. Molecular predictors of outcome with gefitinib and docetaxel in previously treated non-small-cell lung cancer: data from the randomized phase III INTEREST trial. J Clin Oncol. 2010; 28:744-52.

43. Hirsch FR, Varella-Garcia M, Bunn PA Jr, Franklin WA, Dziadziuszko R, Thatcher N, Chang A, Parikh P, Pereira JR, Ciuleanu T, von Pawel J, Watkins C, Flannery A, et al. Molecular predictors of outcome with gefitinib in a phase
III placebo-controlled study in advanced non-small-cell lung cancer. J Clin Oncol. 2006; 24:5034-42.

44. Maemondo $\mathrm{M}$, Inoue $\mathrm{A}$, Kobayashi $\mathrm{K}$, Sugawara $\mathrm{S}$, Oizumi S, Isobe H, Gemma A, Harada M, Yoshizawa H, Kinoshita I, Fujita Y, Okinaga S, Hirano H, et al. Gefitinib or chemotherapy for non-small-cell lung cancer with mutated EGFR. N Engl J Med. 2010; 362:2380-8.

45. Bai H, Wang Z, Chen K, Zhao J, Lee JJ, Wang S, Zhou Q, Zhuo M, Mao L, An T, Duan J, Yang L, Wu M, et al. Influence of chemotherapy on EGFR mutation status among patients with non-small-cell lung cancer. J Clin Oncol. 2012; 30:3077-83.

46. Wang S, An T, Duan J, Zhang L, Wu M, Zhou Q, Chen J, Zhuo M, Yang L, Wang Y, Bai H, Wang J. Alterations in EGFR and related genes following neo-adjuvant chemotherapy in Chinese patients with non-small cell lung cancer. PLoS One. 2013; 8:e51021.

47. Zhang Q, Dai HH, Dong HY, Sun CT, Yang Z, Han JQ. EGFR mutations and clinical outcomes of chemotherapy for advanced non-small cell lung cancer: a meta-analysis. Lung Cancer. 2014; 85:339-45.

48. Gerlinger M, Rowan AJ, Horswell S, Larkin J, Endesfelder D, Gronroos E, Martinez P, Matthews N, Stewart A, Tarpey P, Varela I, Phillimore B, Begum S, et al. Intratumor heterogeneity and branched evolution revealed by multiregion sequencing. N Engl J Med. 2012; 366:883-92.

49. de Bruin EC, McGranahan N, Mitter R, Salm M, Wedge DC, Yates L, Jamal-Hanjani M, Shafi S, Murugaesu N, Rowan AJ, Grönroos E, Muhammad MA, Horswell S, et al. Spatial and temporal diversity in genomic instability processes defines lung cancer evolution. Science. 2014; 346:251-6.

50. Zhang J, Fujimoto J, Zhang J, Wedge DC, Song X, Zhang J, Seth S, Chow CW, Cao Y, Gumbs C, Gold KA, Kalhor N, Little L, et al. Intratumor heterogeneity in localized lung adenocarcinomas delineated by multiregion sequencing. Science. 2014; 346:256-9.

51. Vignot S, Frampton GM, Soria JC, Yelensky R, Commo F, Brambilla C, Palmer G, Moro-Sibilot D, Ross JS, Cronin MT, André F, Stephens PJ, Lazar V, et al. Nextgeneration sequencing reveals high concordance of recurrent somatic alterations between primary tumor and metastases from patients with non-small-cell lung cancer. J Clin Oncol. 2013; 31:2167-72.

52. Shepherd FA, Rodrigues Pereira J, Ciuleanu T, Tan EH, Hirsh V, Thongprasert S, Campos D, Maoleekoonpiroj S, Smylie M, Martins R, van Kooten M, Dediu M, Findlay B, et al. Erlotinib in previously treated non-small-cell lung cancer. N Engl J Med. 2005; 353:123-32.

53. Thatcher N, Chang A, Parikh P, Rodrigues Pereira J, Ciuleanu T, von Pawel J, Thongprasert S, Tan EH, Pemberton K, Archer V, Carroll K. Gefitinib plus best supportive care in previously treated patients with refractory advanced non-small-cell lung cancer: results from a randomised, placebo-controlled, multicentre study (Iressa Survival Evaluation in Lung Cancer). Lancet. 2005; 366:1527-37. 
54. Adamo V, Franchina T, Adamo B, Denaro N, Gambadauro P, Chiofalo G, Scimone A, Caristi N, Russo A, Giordano A. Gefitinib in lung cancer therapy: clinical results, predictive markers of response and future perspectives. Cancer Biol Ther. 2009; 8:206-12.

55. Herbst RS, Giaccone G, Schiller JH, Natale RB, Miller V, Manegold C, Scagliotti G, Rosell R, Oliff I, Reeves JA, Wolf MK, Krebs AD, Averbuch SD, Ochs JS, et al. Gefitinib in combination with paclitaxel and carboplatin in advanced non-small-cell lung cancer: a phase III trialINTACT 2. J Clin Oncol. 2004; 22:785-94.

56. Giaccone G, Herbst RS, Manegold C, Scagliotti G, Rosell R, Miller V, Natale RB, Schiller JH, Von Pawel J, Pluzanska A, Gatzemeier U, Grous J, Ochs JS, et al. Gefitinib in combination with gemcitabine and cisplatin in advanced non-small-cell lung cancer: a phase III trialINTACT 1. J Clin Oncol. 2004; 22:777-84.

57. Herbst RS, Prager D, Hermann R, Fehrenbacher L, Johnson BE, Sandler A, Kris MG, Tran HT, Klein P, Li X, Ramies D, Johnson DH, Miller VA TRIBUTE Investigator Group . TRIBUTE: a phase III trial of erlotinib hydrochloride (OSI-774) combined with carboplatin and paclitaxel chemotherapy in advanced non-small-cell lung cancer. J Clin Oncol. 2005; 28:S32-7.

58. Gatzemeier U, Pluzanska A, Szczesna A, Kaukel E, Roubec J, De Rosa F, Milanowski J, KarnickaMlodkowski H, Pesek M, Serwatowski P, Ramlau R, Janaskova T, Vansteenkiste J, et al. Phase III study of erlotinib in combination with cisplatin and gemcitabine in advanced non-small-cell lung cancer: the Tarceva Lung Cancer Investigation Trial. J Clin Oncol. 2007; 25:1545-52.

59. Hirsch FR, Varella-Garcia M, Cappuzzo F. Predictive value of EGFR and HER2 overexpression in advanced nonsmall-cell lung cancer. Oncogene. 2009; 24:S32-7.

60. Ricciardi GR, Russo A, Franchina T, Ferraro G, Zanghì M, Picone A, Scimone A, Adamo V. NSCLC and HER2: between lights and shadows. J Thorac Oncol. 2014; 9:1750-62.

61. Inoue A, Suzuki T, Fukuhara T, Maemondo M, Kimura Y, Morikawa N, Watanabe H, Saijo Y, Nukiwa T. Prospective phase II study of gefitinib for chemotherapy-naive patients with advanced non-small-cell lung cancer with epidermal growth factor receptor gene mutations. J Clin Oncol. 2006; 24:3340-6.

62. Sutani A, Nagai Y, Udagawa K, Uchida Y, Koyama N, Murayama Y, Tanaka T, Miyazawa H, Nagata M, Kanazawa M, Hagiwara K, Kobayashi K. Gefitinib for nonsmall-cell lung cancer patients with epidermal growth factor receptor gene mutations screened by peptide nucleic acidlocked nucleic acid PCR clamp. Br J Cancer. 2006; 95:1483-9.

63. Mok TS, Wu YL, Thongprasert S, Yang CH, Chu DT, Saijo N, Sunpaweravong P, Han B, Margono B, Ichinose Y, Nishiwaki Y, Ohe Y, Yang JJ, et al. Gefitinib or carboplatin-paclitaxel in pulmonary adenocarcinoma. N Engl J Med. 2009; 361:947-57.
64. Han JY, Park K, Kim SW, Lee DH, Kim HY, Kim HT, Ahn MJ, Yun T, Ahn JS, Suh C, Lee JS, Yoon SJ, Han JH, et al. First-SIGNAL: first-line single-agent iressa versus gemcitabine and cisplatin trial in never-smokers with adenocarcinoma of the lung. J Clin Oncol. 2012; 30:1122-8-8.

65. Zhou C, Wu YL, Chen G, Feng J, Liu XQ, Wang C, Zhang S, Wang J, Zhou S, Ren S, Lu S, Zhang L, Hu C, et al. Erlotinib versus chemotherapy as first-line treatment for patients with advanced EGFR mutation-positive non-small-cell lung cancer (OPTIMAL, CTONG-0802): a multicentre, open-label, randomised, phase 3 study. Lancet Oncol. 2011; 12:735-42.

66. Rosell R, Carcereny E, Gervais R, Vergnenegre A, Massuti B, Felip E, Palmero R, Garcia-Gomez R, Pallares C, Sanchez JM, Porta R, Cobo M, Garrido P, et al. Erlotinib versus standard chemotherapy as first-line treatment for European patients with advanced EGFR mutation-positive non-small-cell lung cancer (EURTAC): a multicentre, open-label, randomised phase 3 trial. Lancet Oncol. 2012; 13:239-46.

67. Cortot AB, Jänne PA. Molecular mechanisms of resistance in epidermal growth factor receptor-mutant lung adenocarcinomas. Eur Respir Rev. 2014; 23:356-66.

68. Lovly CM, Shaw AT. Molecular pathways: resistance to kinase inhibitors and implications for therapeutic strategies. Clin Cancer Res. 2014; 20:2249-56.

69. Sequist LV, Waltman BA, Dias-Santagata D, Digumarthy S, Turke AB, Fidias P, Bergethon K, Shaw AT, Gettinger S, Cosper AK, Akhavanfard S, Heist RS, Temel J, et al. Genotypic and histological evolution of lung cancers acquiring resistance to EGFR inhibitors. Sci Transl Med. 2011; 3:75ra26.

70. Yu HA, Arcila ME, Rekhtman N, Sima CS, Zakowski MF, Pao W, Kris MG, Miller VA, Ladanyi M, Riely GJ. Analysis of tumor specimens at the time of acquired resistance to EGFR-TKI therapy in 155 patients with EGFR-mutant lung cancers. Clin Cancer Res. 2013; 19:2240-7.

71. Yu HA, Riely GJ, Lovly CM. Therapeutic Strategies Utilized in the Setting of Acquired Resistance to EGFR Tyrosine Kinase Inhibitors. Clin Cancer Res. 2014; 20:5898-5907.

72. Rolfo C, Giovannetti E, Hong DS, Bivona T, Raez LE, Bronte G, Buffoni L, Reguart N, Santos ES, Germonpre P, Taron M, Passiglia F, Van Meerbeeck JP, et al. Novel therapeutic strategies for patients with NSCLC that do not respond to treatment with EGFR inhibitors. Cancer Treat Rev. 2014; 40:990-1004.

73. Kwak EL, Sordella R, Bell DW, Godin-Heymann N, Okimoto RA, Brannigan BW, Harris PL, Driscoll DR, Fidias P, Lynch TJ, Rabindran SK, McGinnis JP, Wissner A, et al. Irreversible inhibitors of the EGF receptor may circumvent acquired resistance to gefitinib. Proc Natl Acad Sci U S A. 2005; 102:7665-70.

74. Engelman JA, Zejnullahu K, Gale CM, Lifshits E, Gonzales AJ, Shimamura T, Zhao F, Vincent PW, 
Naumov GN, Bradner JE, Althaus IW, Gandhi L, Shapiro GI, et al. PF00299804, an irreversible pan-ERBB inhibitor, is effective in lung cancer models with EGFR and ERBB2 mutations that are resistant to gefitinib. Cancer Res. 2007; 67:11924-32.

75. Li D, Ambrogio L, Shimamura T, Kubo S, Takahashi M, Chirieac LR, Padera RF, Shapiro GI, Baum A, Himmelsbach F, Rettig WJ, Meyerson M, Solca F, et al. BIBW2992, an irreversible EGFR/HER2 inhibitor highly effective in preclinical lung cancer models. Oncogene. 2008; 27:4702-11.

76. Miller VA, Hirsh V, Cadranel J, Chen YM, Park K, Kim SW, Zhou C, Su WC, Wang M, Sun Y, Heo DS, Crino L, Tan EH, et al. Afatinib versus placebo for patients with advanced, metastatic non-small-cell lung cancer after failure of erlotinib, gefitinib, or both, and one or two lines of chemotherapy (LUX-Lung 1): a phase 2b/3 randomised trial. Lancet Oncol. 2012; 13:528-38.

77. Sequist LV, Besse B, Lynch TJ, Miller VA, Wong KK, Gitlitz B, Eaton K, Zacharchuk C, Freyman A, Powell C, Ananthakrishnan R, Quinn S, Soria JC. Neratinib, an irreversible pan-ErbB receptor tyrosine kinase inhibitor: results of a phase II trial in patients with advanced non-small-cell lung cancer. J Clin Oncol. 2010; 28:3076-83.

78. Reckamp KL, Giaccone G, Camidge DR, Gadgeel SM, Khuri FR, Engelman JA, Koczywas M, Rajan A, Campbell AK, Gernhardt D, Ruiz-Garcia A, Letrent S, Liang J, et al. A phase 2 trial of dacomitinib (PF-00299804), an oral, irreversible pan-HER (human epidermal growth factor receptor) inhibitor, in patients with advanced nonsmall cell lung cancer after failure of prior chemotherapy and erlotinib. Cancer. 2014; 120:1145-54.

79. Sequist LV, Yang JC, Yamamoto N, O'Byrne K, Hirsh V, Mok T, Geater SL, Orlov S, Tsai CM, Boyer M, Su WC, Bennouna J, Kato T, et al. Phase III study of afatinib or cisplatin plus pemetrexed in patients with metastatic lung adenocarcinoma with EGFR mutations. J Clin Oncol. 2013; 31:3327-34.

80. Wu YL, Zhou C, Hu CP, Feng J, Lu S, Huang Y, Li W, Hou M, Shi JH, Lee KY, Xu CR, Massey D, Kim M, et al. Afatinib versus cisplatin plus gemcitabine for first-line treatment of Asian patients with advanced non-small-cell lung cancer harbouring EGFR mutations (LUX-Lung 6): an open-label, randomised phase 3 trial. Lancet Oncol. 2014; 15:213-22.

81. Jänne PA, Ou SH, Kim DW, Oxnard GR, Martins R, Kris MG, Dunphy F, Nishio M, O'Connell J, Paweletz C, Taylor I, Zhang H, Goldberg Z, et al. Dacomitinib as firstline treatment in patients with clinically or molecularly selected advanced non-small-cell lung cancer: a multicentre, open-label, phase 2 trial. Lancet Oncol. 2014; 15:1433-41.

82. Janjigian YY, Smit EF, Groen HJ, Horn L, Gettinger S, Camidge DR, Riely GJ, Wang B, Fu Y, Chand VK, Miller VA, Pao W. Dual inhibition of EGFR with afatinib and cetuximab in kinase inhibitor-resistant EGFR-mutant lung cancer with and without T790M mutations. Cancer Discov. 2014; 4:1036-45.

83. Gandhi L, Bahleda R, Tolaney SM, Kwak EL, Cleary JM, Pandya SS, Hollebecque A, Abbas R, Ananthakrishnan R, Berkenblit A, Krygowski M, Liang Y, Turnbull KW, et al. Phase I study of neratinib in combination with temsirolimus in patients with human epidermal growth factor receptor 2-dependent and other solid tumors. J Clin Oncol. 2014; 32:68-75.

84. Zhou W, Ercan D, Chen L, Yun CH, Li D, Capelletti M, Cortot AB, Chirieac L, Iacob RE, Padera R, Engen JR, Wong KK, Eck MJ, et al. Novel mutant-selective EGFR kinase inhibitors against EGFR T790M. Nature. 2009; 462:1070-4.

85. Walter AO, Sjin RT, Haringsma HJ, Ohashi K, Sun J, Lee K, Dubrovskiy A, Labenski M, Zhu Z, Wang Z, Sheets M, St Martin T, Karp R, et al. Discovery of a mutant-selective covalent inhibitor of EGFR that overcomes T790M-mediated resistance in NSCLC. Cancer Discov. 2013; 3:1404-15.

86. Sequist LV, Soria JC, Goldman JW, Wakelee HA, Gadgeel SM, Varga A, Papadimitrakopoulou V, Solomon BJ, Oxnard GR, Dziadziuszko R, Aisner DL, Doebele RC, Galasso C, et al. Rociletinib in EGFRmutated non-small-cell lung cancer. N Engl J Med. 2015; 372:1700-9.

87. Cross DA, Ashton SE, Ghiorghiu S, Eberlein C, Nebhan CA, Spitzler PJ, Orme JP, Finlay MR, Ward RA, Mellor MJ, Hughes G, Rahi A, Jacobs VN, et al. AZD9291, an irreversible EGFR TKI, overcomes T790M-mediated resistance to EGFR inhibitors in lung cancer. Cancer Discov. 2014; 4:1046-61.

88. Takezawa K, Pirazzoli V, Arcila ME, Nebhan CA, Song X, de Stanchina E, Ohashi K, Janjigian YY, Spitzler PJ, Melnick MA, Riely GJ, Kris MG, Miller VA, et al. HER2 amplification: a potential mechanism of acquired resistance to EGFR inhibition in EGFR-mutant lung cancers that lack the second-site EGFRT790M mutation. Cancer Discov. 2012; 2:922-33.

89. Jänne PA, Yang JC, Kim DW, Planchard D, Ohe Y, Ramalingam SS, Ahn MJ, Kim SW, Su WC, Horn L, Haggstrom D, Felip E, Kim JH, et al. AZD9291 in EGFR inhibitor-resistant non-small-cell lung cancer. N Engl J Med. 2015; 372:1689-99.

90. Kim DW, Lee DH, Kang JH, Park K, Han JY, Lee JS, Jang IJ, Kim HY, Son J, Kim JH. Clinical activity and safety of HM61713, an EGFR-mutant selective inhibitor, in advanced non-small cell lung cancer (NSCLC) patients (pts) with EGFR mutations who had received EGFR tyrosine kinase inhibitors (TKIs). J Clin Oncol. $32: 5$ s 2014.

91. Zimmermann S, Dziadziuszko R, Peters S. Indications and limitations of chemotherapy and targeted agents in nonsmall cell lung cancer brain metastases. Cancer Treat Rev. 2014; 40:716-22. 
92. Franceschi E, Bartolotti M, Poggi R, Di Battista M, Palleschi D, Brandes AA. The role of systemic and targeted therapies in brain metastases. Expert Rev Anticancer Ther. 2014; 14:93-103.

93. Iuchi T, Shingyoji M, Sakaida T, Hatano K, Nagano O, Itakura M, Kageyama H, Yokoi S, Hasegawa Y, Kawasaki K, Iizasa T. Phase II trial of gefitinib alone without radiation therapy for Japanese patients with brain metastases from EGFR-mutant lung adenocarcinoma. Lung Cancer. 2013; 82:282-7.

94. Camidge DR, Pao W, Sequist LV. Acquired resistance to TKIs in solid tumours: learning from lung cancer. Nat Rev Clin Oncol. 2014; 11:473-81.

95. Grommes C, Oxnard GR, Kris MG, Miller VA, Pao W, Holodny AI, Clarke JL, Lassman AB. "Pulsatile" highdose weekly erlotinib for CNS metastases from EGFR mutant non-small cell lung cancer. Neuro Oncol. 2011; $13: 1364-9$

96. Weickhardt AJ, Scheier B, Burke JM, Gan G, Lu X, Bunn PA Jr, Aisner DL, Gaspar LE, Kavanagh BD, Doebele RC, Camidge DR. Local ablative therapy of oligoprogressive disease prolongs disease control by tyrosine kinase inhibitors in oncogene-addicted non-small-cell lung cancer. J Thorac Oncol. 2012; 7:1807-14.

97. Yu HA, Sima CS, Huang J, Solomon SB, Rimner A, Paik P, Pietanza MC, Azzoli CG, Rizvi NA, Krug LM, Miller VA, Kris MG, Riely GJ. Local therapy with continued EGFR tyrosine kinase inhibitor therapy as a treatment strategy in EGFR-mutant advanced lung cancers that have developed acquired resistance to EGFR tyrosine kinase inhibitors. J Thorac Oncol. 2013; 8:346-51.

98. Goss GD, O'Callaghan C, Lorimer I, Tsao MS, Masters GA, Jett J, Edelman MJ, Lilenbaum R, Choy H, Khuri F, Pisters K, Gandara D, Kernstine K, et al. Gefitinib versus placebo in completely resected non-small-cell lung cancer: results of the NCIC CTG BR19 study. J Clin Oncol. 2013; 31:3320-6.

99. Kelly K, Chansky K, Gaspar LE, Albain KS, Jett J, Ung YC, Lau DH, Crowley JJ, Gandara DR. Phase III trial of maintenance gefitinib or placebo after concurrent chemoradiotherapy and docetaxel consolidation in inoperable stage III non-small-cell lung cancer: SWOG S0023. J Clin Oncol. 2008; 26:2450-6.

100. Shepherd FA, Altorki NK, Eberhardt WE, O'Brien ME, Spigel DR, Crinò L, et al. Adjuvant erlotinib (E) versus placebo (P) in non-small cell lung cancer (NSCLC) patients (pts) with tumors carrying EGFR-sensitizing mutations from the RADIANT trial. J Clin Oncol. 32:5s, 2014.

101. Kelly K, Altorki NK, Eberhardt WE, O'Brien ME, Spigel DR, Crinò L, Tsai CM, Kim JH, Cho EK, Szczesna A, Burghuber O, Hoffman PC, Keshavjee S, et al. A randomized, double-blind phase 3 trial of adjuvant erlotinib (E) versus placebo $(\mathrm{P})$ following complete tumor resection with or without adjuvant chemotherapy in patients (pts) with stage IB-IIIA EGFR positive (IHC/
FISH) non-small cell lung cancer (NSCLC): RADIANT results. J Clin Oncol. 32:5s, 2014.

102. D'Angelo SP, Janjigian YY, Ahye N, Riely GJ, Chaft JE, Sima CS, Shen R, Zheng J, Dycoco J, Kris MG, Zakowski MF, Ladanyi M, Rusch V, et al. Distinct clinical course of EGFR-mutant resected lung cancers: results of testing of 1118 surgical specimens and effects of adjuvant gefitinib and erlotinib. J Thorac Oncol. 2012; 7:1815-22.

103. De Pas T, Toffalorio F, Manzotti M, Fumagalli C, Spitaleri G, Catania C, Delmonte A, Giovannini M, Spaggiari L, de Braud F, Barberis M. Activity of epidermal growth factor receptor-tyrosine kinase inhibitors in patients with non-small cell lung cancer harboring rare epidermal growth factor receptor mutations. J Thorac Oncol. 2011; 6:1895-901.

104. Yang JC, Sequist LV, Geater SL, Tsai CM, Mok T, Schuler MH, Yamamoto N, Massey D, Zazulina V, $\mathrm{Wu}$ YL. Activity of Afatinib in uncommon Epidermal Growth Factor Receptor (EGFR) mutations: findings from three trials of afatinib in EGFR mutation-positive lung cancer. J Thorac Oncol. 2013; 8:S141.

105. Beau-Faller M, Prim N, Ruppert AM, Nanni-Metéllus I, Lacave R, Lacroix L, Escande F, Lizard S, Pretet JL, Rouquette I, de Crémoux P, Solassol J, de Fraipont F, et al. Rare EGFR exon 18 and exon 20 mutations in nonsmall-cell lung cancer on 10117 patients: a multicentre observational study by the French ERMETIC-IFCT network. Ann Oncol. 2014; 25:126-31.

106. Tsigelny IF, Wheler JJ, Greenberg JP, Kouznetsova VL, Stewart DJ, Bazhenova L, Kurzrock R. Molecular determinants of drug-specific sensitivity for epidermal growth factor receptor (EGFR) exon 19 and 20 mutants in non-small cell lung cancer. Oncotarget. 2015; Mar 20; 6:6029-39.

107. Mitsudomi T, Morita S, Yatabe Y, Negoro S, Okamoto I, Tsurutani J, Seto T, Satouchi M, Tada H, Hirashima T, Asami K, Katakami N, Takada M, et al. Updated overall survival results of WJTOG 3405, a randomized phase III trial comparing gefitinib $(\mathrm{G})$ with cisplatin plus docetaxel (CD) as the first-line treatment for patients with non-small cell lung cancer harboring mutations of the epidermal growth factor receptor (EGFR). J Clin Oncol. 30; 2012.

108. Inoue A, Kobayashi $\mathrm{K}$, Maemondo M, Sugawara S, Oizumi S, Isobe H, Gemma A, Harada M, Yoshizawa H, Kinoshita I, Fujita Y, Okinaga S, Hirano H, et al. Updated overall survival results from a randomized phase III trial comparing gefitinib with carboplatin-paclitaxel for chemonaive non-small cell lung cancer with sensitive EGFR gene mutations (NEJ002). Ann Oncol. 2013; 24:54-59.

109. Zhou C, Wu YL, Liu X, Wang C, Chen G, Feng J, Zhang S, Wang J, Zhou S, Ren S, Lu S, Zhang L, Hu CP, et al. Overall survival (OS) results from OPTIMAL (CTONG0802), a phase III trial of erlotinib (E) versus carboplatin plus gemcitabine (GC) as first-line treatment for Chinese patients with EGFR mutation-positive advanced non-small cell lung cancer (NSCLC). J Clin Oncol. 30:2012. 